\title{
3D-PTV を用いた水中気泡噴流の基本構造
}

\author{
川口 遼 (同志社)，舟木 治郎 (同志社)，平田 勝哉（同志社） \\ The Basic Structure of a Bubble Jet in Water \\ Using 3D-PTV \\ Ryo KAWAGUCHI, Jiro FUNAKI and Katsuya HIRATA
}

\begin{abstract}
The bubble flow often becomes a key phenomenon in diverse engineering aspects. However, bubble flows have not been clear yet. In this research, we reveal basic features of a simple air on bubble-jet flow in water quantitatively. Specifically speaking, we try to apply a three-dimensional particle tracking velocimetry (3D-PTV) to the bubble-jet flow, and to show velocity vectors of bubbles. Air bubbles are shed from a nozzle in a large water tank. The tilting angle effect of the nozzle is investigated. As a result, the tilting-angle effect makes small bubbles less than $0.5[\mathrm{~mm}]$ rise outside the bubble-jet centre core.
\end{abstract}

Keywords: Bubble Jet, Three-Dimension, Flow Visualization, PTV

\section{1. 緒 論}

近年，湖や池，港湾などでは富栄養化による水質污染 が見られる。この水質污染を改善するための簡単な方法 の一つに，気泡噴流（曝気）を用いて水中に酸素を送り 込む方法がある，この他の気泡噴流の忍用例として，原 子カプラントや化学プラント, 気泡塔やバイオリアクタ 一, さらには化学反応器や, 気泡ポンプなどが挙げられ る.このように，水中もしくは他の流体中での気泡運動 は様々な用途に幅広く応用されているが，これらの気泡 群の運動は，ままりわかっていない。

本研究では，最も単純で基本的な水中におり河気泡噴 流を考えて，その空間構造を定量的に明らかにする．具 体的には，3D-PTV(Three-Dimensional Particle Tracking Velocimetry)を気泡噴流に適用して，個々の気 泡の運動を定量的に求めることを試みる.3D-PTVとは, 一対のステレオ画像加らトレーサ一粒子の 3 次元位置を 算出し，連続するトレーサ一粒子の位置情報から粒子の 速度ベクトルを得る手法である(1)(2)．本実験では気泡を トレーサー粒子として適用することを試みている。

\section{2. 実験装置と実験方法}

Fig. 1 は実験装置の概略図である。空気は，圧縮機(2) で加圧され，充分大きな水槽(1)内部のチャンバー(5)から ノズルを通して，水中に噴出する。

ノズルからの気泡噴流全体を観察するために，ノズル 先端加ら水面付近までの広範囲の画像を撮影する。使用 したノズルは内径 $0.1[\mathrm{~mm}]$ ，管長さ $15[\mathrm{~mm}]$ のストレー トパイプノズルである、また，噴出角度 $\alpha$ は鉛直上方 $(0[\mathrm{deg}])$ と, 水平方向 $(90[\mathrm{deg}]) の 2$ 種類の状態で実験を行
う.このとき, 圧力比 $p_{\infty} / p_{0}=0.85 \sim 0.20$ の範囲内で実験 を行っている。

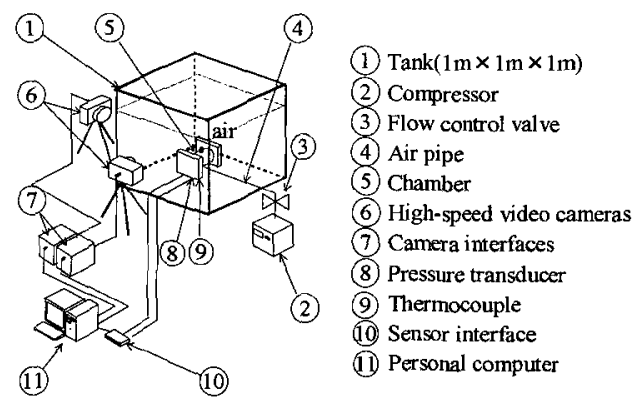

Fig. 1 Experimental apparatus

\section{3. 結果と考察}

\section{1 気泡噴流全体画像}

Fig. 2 は，ある珐力比における気泡噴流の全体画像で ある.図(a)はノズルの向き $\alpha=0[\mathrm{deg}]$, 困(b)は $\alpha=90$ [deg] の場合である。

$\alpha=0,90$ [deg] ともに，1〜3mm の大な気泡が気泡噴 流の明瞭な核を形成する， $\alpha=0[\mathrm{deg}]$ では， $0.5[\mathrm{~mm}]$ 以下 の微細な気泡が気泡噴流核の内側のみならず，外側の広

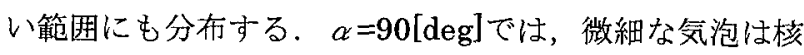
内部にはほとんど存在せず，核よりもノズルから若干遠 方に存在しがちである。この核からの偏りは $p_{\infty} / p_{0}$ が低 くなるほど顕著になる。 


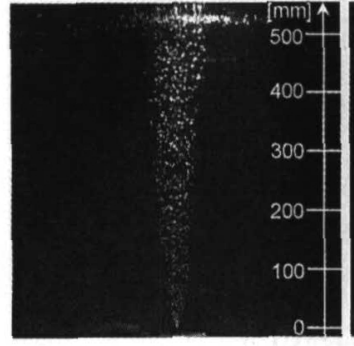

$\alpha=0[\mathrm{deg}]$

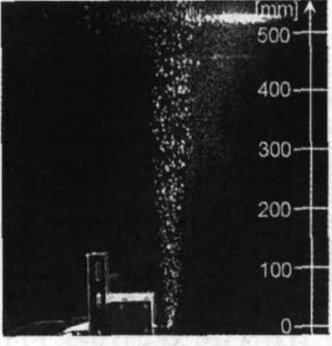

$\alpha=90[\mathrm{deg}]$
Fig. 2 A pair of Bubble jet images at $p_{\infty} / p_{0}=0.42$

\section{2 気泡噴流の 3D-PTV 計測}

Fig. 3 は 3D-PTV の計測結果の一例である. 全体の流 れ場は鉛直方向に広いので, 高い空間分解能を得るため, 領域を 2 つに分けている。すすおわ，水槽底部に近い Lower region(図(a)) とその上部 Upper region(図(b))で ある。なお，図(a)，(b)は，カメラ台数の制限のため，同 時計測されたものではない.

Fig. 3 は $\alpha=90[\mathrm{deg}]$ の結果であるが, 速度絶対值の大 きい気泡群と小さいものに分かれている，速度の大きい 気泡群の位置は可視化による噴流核の位置とよく対応し ている，さらに，その速度の絶対値は，単一気泡を考え て $2[\mathrm{~mm}]$ 以上の径をもつ気泡の值とよい一致を示す。一 方, 速度の小さい気泡群の位置は可視化の結果より得ら れた微細な気泡群 $(0.5[\mathrm{~mm}]$ 以下 $)$ の位置とよく一致する. さらに, その速度の絶対值は, 単一気泡のそれとよい一 致を示す.

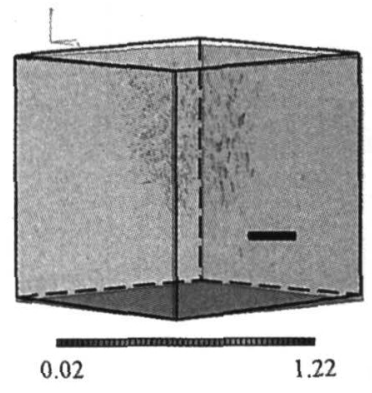

(a)Lower region

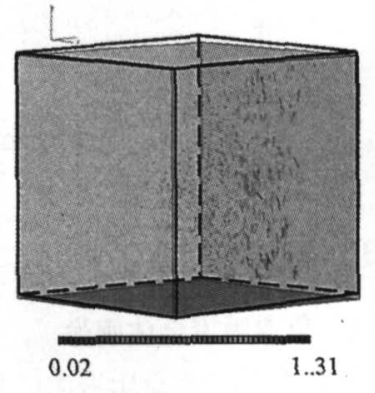

(b)Upper region
Fig. 3 Velocity vectors of the bubbles shed from a pipe nozzle with $\alpha=90[\mathrm{deg}]$

\section{$3.3 z$ 方向における気泡速度分布}

先の 3D-PTVにより, 我々は気泡の三次元速度ベクト ルを多量に得ることができる，今回，その結果を統計処 理することにより, 気泡噴流の時間平均空間構造を明ら かにする、ここで，座標系は円柱系 $(r, \theta, z)$ を考える。， ズル出口中心を原点として, 半径方向を $r$, 鉛直方向を $z$ とする.

Fig. 4(a)より,$p_{\infty} / p_{0}=0.5$ までは圧力比が小さくな
るにつれて, 気泡平均速度も小さくなる.また, $p_{\infty} / p_{0}=0.5$ より小さくなると気泡平均速度はほぼ一定となる。これ は, 圧力比が小さくなるに従い，速度のおそい微細な気 泡が多く発生するためである，とくに， $p_{\infty} / p_{0}=0.5$ まで は微細な気泡が噴流核中心付近に位置し, それ以後, 噴 流核全体に広く位置するようになる。このことより， $p_{\infty}$ $/ p_{0}=0.5$ を境に気泡平均速度がほぼ一定となる.

Fig. 4 (b)については, (a)のような大きな変化はない. これは先に述べたように, 気泡平均速度が小さくなるの は微細な気泡の存在比率によるものだとすると，a $=90[\mathrm{deg}]$ では可視化画像からもわかるとおり，噴流核中

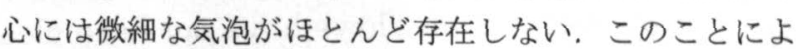
り, 気泡平均速度は圧力比を変化させても明瞭な変化が 現れない.

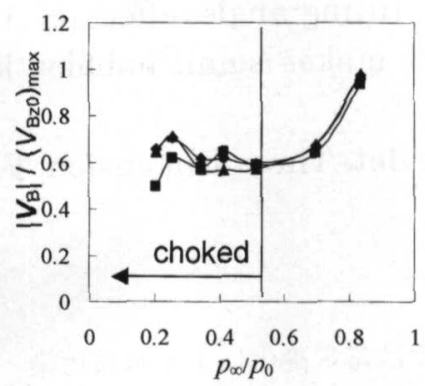

(a) $\alpha=0$ [deg]

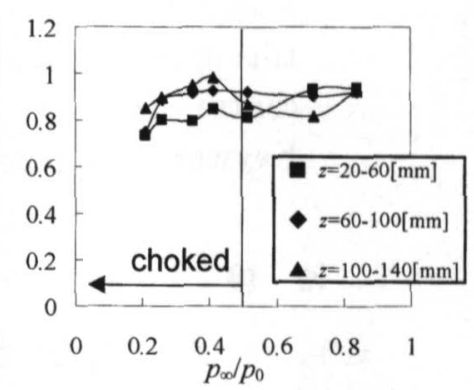

(b) $\alpha=90$ [deg]
Fig. 4 Bubble's velocity against pressure ratio near the centre (at $r=0-5$ )

\section{4. 結言}

（1）水中における気泡噴流について,気泡の運動を瞬間 的にとらえることができる. その基本特性を定量的 に明らかにするために 3D PTV 解析手法を用いた 計測を実施した. ハイスピードカメラの使用により 連続的変化も観察可能となった。

（2）ノズルの噴出角度 $\alpha$ を水平方向に変えると 0.5 $[\mathrm{mm}]$ 以下の微細な気泡が気泡噴流から離れて上昇 する現象が見られた。

（3）ノズル噴出角度 $\alpha=0[\mathrm{deg}]$ (鉛直上方)の場合, ノズル 出口から 20 140 [mm]において, 圧力比 $p_{\infty} / p_{0} \leqq$ 0.5 で気泡噴流の中心軸まわりでは，気泡平均速度 が最小值をとる.

（4） $\alpha=90[\mathrm{deg}]$ (水平)の場合, 圧力比を変化させても中 心軸付近での気泡平均速度に明瞭な変化はない。

\section{参 考 文 献}

1) D. H. Doh, D. H. Kim, et a1: Development of Genetic Algorithm Based 3D-PTV Technique Journal of Visualization, Vol.5, No. 3(2002), pp. 243-254

2) Hwang, T. G., Doh, D. H. and Okamoto, K: 4D-PTV, Journal of Visualization, Vo18, No3(2005), pp. 245-252 